\title{
Monitoring programme for underground rock characterization facility
}

\author{
K. Lehto \& J. Lahdenperä \\ Posiva Oy, Finland
}

\begin{abstract}
Posiva is a Finnish nuclear waste management company with the duty to take care of the high-level nuclear waste produced in Finland. Pursuant to the Decision-in-Principle of 2001 Posiva has moved to the phase of underground characterisation of the repository site. The main objective of this phase is to confirm the suitability of the Olkiluoto site by investigations conducted underground. A programme of monitoring has been launched as part of the investigations and to follow the changes occurring within the site due to the construction. The programme of monitoring started in the year 2004, one year before the construction work. Baseline monitoring was carried out prior to the construction phase and the results gained from monitoring during construction phase are compared to the baseline data. Rock mechanics, hydrology, geochemistry, environment, and the use of foreign materials are included the monitoring programme.

Keywords: monitoring, high-level nuclear waste, hydrology, rock mechanics, geochemistry, environment, foreign materials, underground rock characterization facility.
\end{abstract}

\section{Introduction}

Posiva Oy is a Finnish high-level nuclear waste management company owned by the two Finnish nuclear companies Teollisuuden Voima Oy and Fortum Power \& Heat Oyj. Posiva's duty is to take care of final disposal of spend nuclear fuel. Posiva is established in the year 1996.

In the year 2001, the Finnish Parliament ratified the Decision-in-Principle on the disposal of spent fuel from the Finnish nuclear power reactors. According to the decision, Posiva may concentrate the investigation on one site, Olkiluoto, in 
the municipality of Eurajoki in the western part of Finland. The Decision-inPrinciple also means that the repository would be located at Olkiluoto and the disposal would be based on the KBS-3 concept.

On the year 2004 Posiva started to construct an underground characterization facility called ONKALO, which will be a part of actual high-level waste repository later on. The repository is planned to be in use in the year 2020 .

Before Posiva started to construct ONKALO a baseline monitoring was done. The monitoring results gained during the construction and use of ONKALO will be compared to the data gained during the baseline monitoring.

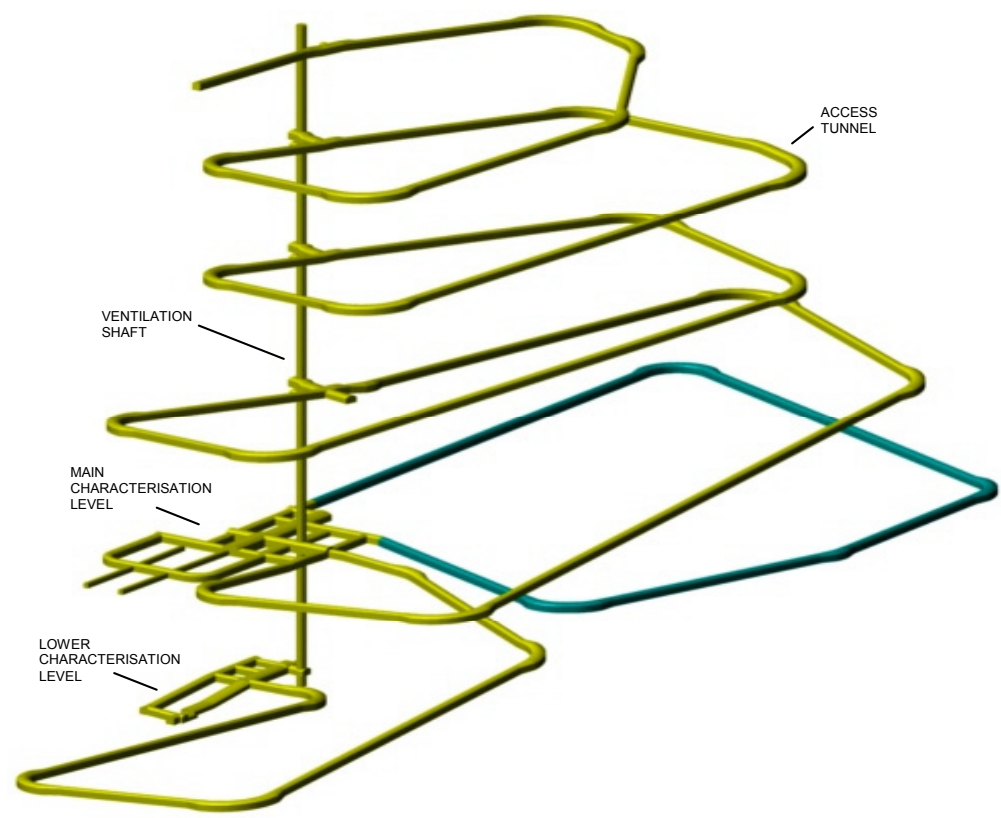

Figure 1: The design of the underground rock characterisation facility at the main drawings stage [6].

\section{ONKALO: underground rock characterization facility}

The construction of the underground rock characterization facility called ONKALO was started in July 2004. By the end of the year 2005 about $990 \mathrm{~m}$ of tunnel has been excavated and the first underground investigations program is implemented. The target depth of the ONKALO is $520 \mathrm{~m}$ below the sea level. The main characterization level is at the depth of $420 \mathrm{~m}$ below the sea level and the lower characterisation level in depth of $520 \mathrm{~m}$ below the sea level, fig. 1. The total length of the tunnels will be about $9 \mathrm{~km}$. The entire facility is planed to be 
ready in the year 2010. ONKALO is planned to be a part of the actual high-level waste repository, which is planned to start its operation in the year 2020 [6].

The construction of the ONKALO and the high-level waste repository will affect the surrounding rock mass and the groundwater flow system as well as the chemical environment on the surface but especially at the greater depths. To determine the magnitude and the extent of effects the programme of monitoring was established. The programme of monitoring at Olkiluoto during construction and operation of underground rock facility was established prior to the construction phase [7].

\section{Programme of monitoring}

Before the programme of monitoring during construction of ONKALO begun a baseline condition of Olkiluoto was reported [5]. The main purpose of the baseline report was to establish a reference point for the following phases of the Finnish spent nuclear fuel disposal programme. The focus of the baseline report was to define the current surface and the underground conditions at the site, to establish the natural fluctuation of properties that are potentially disturbed and to provide the reference data to the models and modellers.

During the construction of ONKALO rock mechanical, hydrological, chemical and environmental monitoring is carried out and the quality and the quantity of the foreign materials used in the construction and investigations is measured and followed [7]. The monitoring is carried out both on the surface and underground. In the Baseline report the current understanding of the investigation site before the constructions of ONKALO started was established. The results gained from monitoring have been and will be compared to the baseline data.

\subsection{Hydrology}

The following parameters have been included in the hydrological monitoring programme:

$\begin{array}{cl}\circ & \text { level of groundwater and seawater table } \\ \circ & \text { hydraulic head } \\ \circ & \text { flow conditions } \\ \circ & \text { in situ salinity } \\ \circ & \text { precipitation } \\ \circ & \text { surface runoff } \\ \bigcirc & \text { infiltration } \\ \circ & \text { soil frost } \\ \circ & \text { water balance in the tunnels }\end{array}$

The hydrological monitoring is carried out from the both on surface and underground. Both the open and the packed-off boreholes are used in the surface based monitoring. The flow conditions, in situ salinities and the hydraulic heads are measured from the open boreholes by Posiva Flow Log measurement device and Posiva's hydraulic testing unit (HTU). 


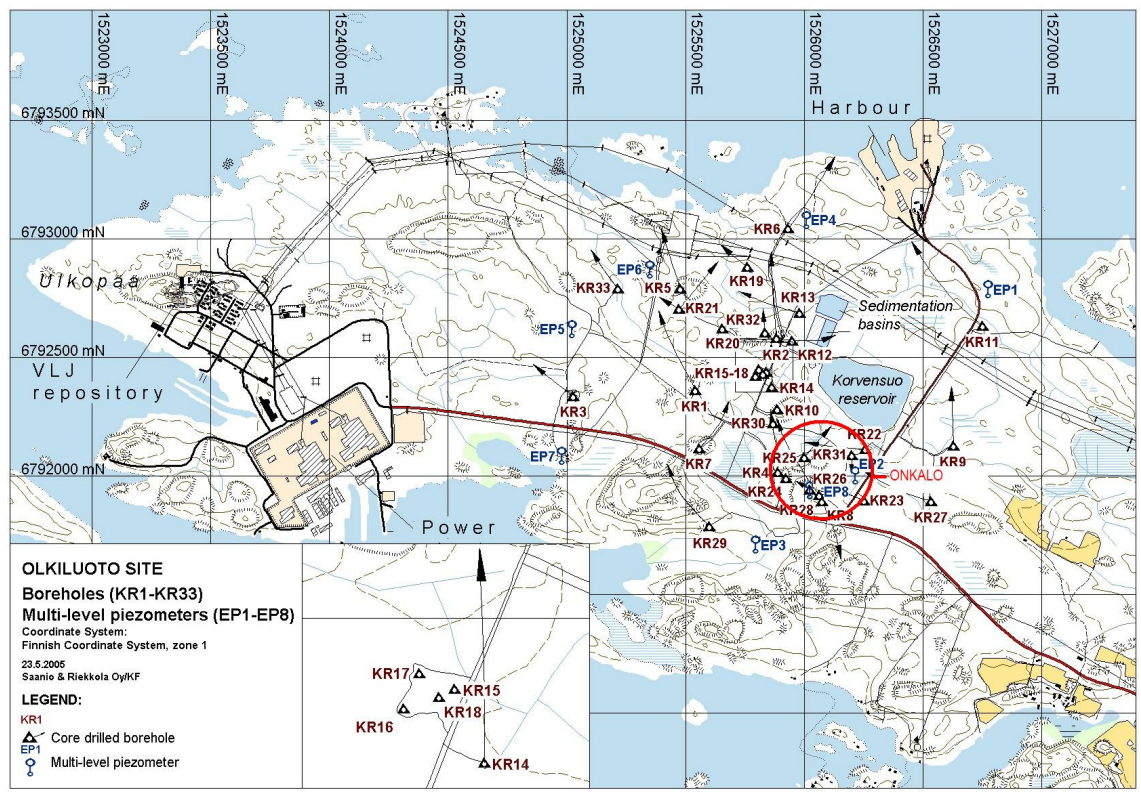

Figure 2: $\quad$ Map of deep drillholes (KR) and multilevel piezometers (EP) in Olkiluoto.

The hydraulic heads and the level of the ground water table are measured from the open and packed off boreholes as well as from the multilevel piezometers, fig 2. The level of water table is measured manually from the open boreholes once a week or month and the hydraulic head automatically from the packed-off boreholes once every ten minute.

The rest of the parameters listed above form a background data for the studies and the analysis of the actual monitoring results [1].

\subsection{Rock mechanics}

A local GPS-network was established at Olkiluoto in the year 1995. It consists of 14 stations one of which belongs to the Finnish permanent GPS network FinnRef $^{\circledR}$. Four of the stations are located outside the island. The purpose of the measurements is to observe long-term large-scale rock movements and land uplift.

Because the GPS-measurements are not sensitive enough, precise levelling is carried out to measure the annual land uplift at the Olkiluoto.

A microseismic network of Olkiluoto was built in 2002. The network consists of 12 stations. Four of the stations are located outside Olkiluoto. In the beginning, the network monitored tectonic earthquakes in order to characterise the baseline of seismicity of the Olkiluoto. When the construction started it also monitors excavation-induced seismicity [9]. 
Later on when construction of ONKALO progresses more measurements such as convergence measurements and acoustic emission will be done and extensometers installed [7].

\subsection{Geochemistry}

The geochemical monitoring programme includes mapping of the changes in the groundwater chemistry caused by the construction and mapping of the influences caused by the engineering and the foreign materials entering ONKALO [3]. Most of the geochemical measurements have taken place from the surface based holes, but some underground sampling is also done.

Groundwater samples have been taken both from the overburden and deep bedrock by different methods. The chemical properties of the water used in the ONKALO and pumped out from there have been analysed.

Possible movement of the saline waters in the bedrock is studied by Gefinex 400 s measurements.

\subsection{Environment}

Environmental monitoring has been carried out for a long time: the environmental monitoring performed by Teollisuuden Voima Oy (TVO) started in the 1970's. TVO is obliged to carry out monitoring of marine environment and also of radioactivity of the environment around Olkiluoto, both in the marine and terrestrial systems and human food chains. Noise, dust and water quality of the private wells are monitored in campaigns. In addition, aerial photographing and characterisation of the flora and fauna is included in the programme [7].

The data gathered through the monitoring is used as input for the biosphere modelling in the long-term safety analysis as well as for the broader environmental impact analysis [2].

\subsection{Foreign materials}

During the construction and operation of the ONKALO several types of foreign materials are introduced to the underground facility, mainly for the engineering purposes. The amount of the materials, such as cement, rock bolts, labelled water etc. is monitored and recorded.

\section{Results}

The monitoring at Olkiluoto is part of the site investigations. The monitoring activities are done continuously or regularly and always in the same way. The programme of monitoring will be updated at the latest in 2012, but maybe earlier.

\subsection{Hydrology}

The results of hydrological monitoring are studied and analysed to determine the effects of the construction of ONKALO on the water balance of the reservoir. 
The total leakage water inflow into ONKALO is about $16 \mathrm{l} / \mathrm{min}$ when length of tunnel in $990 \mathrm{~m}$. Because of the fairly small inflow into ONKALO no long-term hydrological changes have occurred so far, fig 3 .

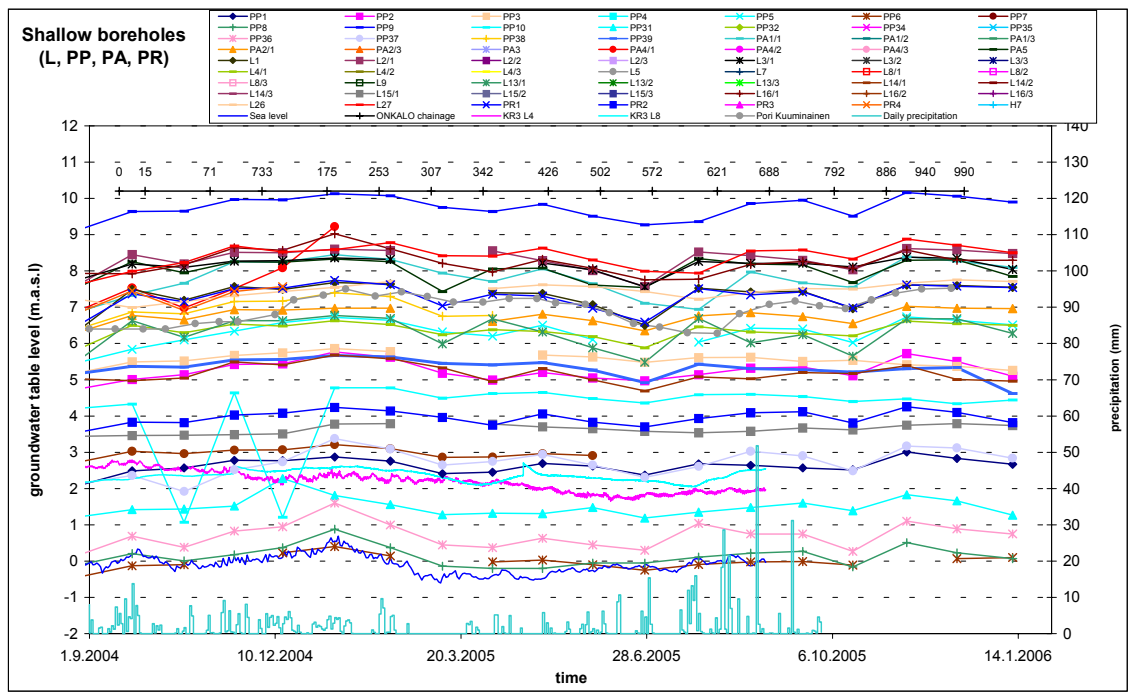

Figure 3: Level of the groundwater table in the shallow boreholes.

\subsection{Rock Mechanics}

The annual land uplift at the Olkiluoto is $6 \mathrm{~mm} /$ year [5]. Precise levelling shows that two areas rise faster than the rest of the island. The reason to this is that lots of the rock masses are moved away from these two areas.

Five of the microseismic events are classified uncertain or unusual. After Saari [10] it is very unlikely that they are microseismic events, but they are not typical examples of an artificial seismic signals, either, table 1 .

No other rock mechanical changes have occurred in Olkiluoto since the construction started.

\subsection{Geochemistry}

Some changes in the main ions can be noticed in the groundwater samples taken from the surface. All the noticed changes are mainly minor and cannot be caused by the ONKALO activities because most of the samples have been collected before the construction took place [3].

No other changes in the geochemistry have been observed.

\subsection{Environment}

No unexplainable deviations from the reference data can be seen so far [2]. 
Table 1: Events of uncertain origin 2002-2004. Loc. Err = location error, Mag Loc $=$ local magnitude, Size $=$ estimated size of the seismic source, ESEP = Energy of S-wave/energy of P-wave and No of Acc $=$ number of recordings used in analysis [10].

\begin{tabular}{|c|c|c|c|c|c|}
\hline No & Date & $\begin{array}{c}\text { Origin } \\
\text { Time } \\
\text { (UTC) }\end{array}$ & $\begin{array}{c}\mathbf{X} \\
\mathbf{( m )}\end{array}$ & $\begin{array}{c}\mathbf{Y} \\
\mathbf{( m )}\end{array}$ & $\begin{array}{c}\mathbf{Z} \\
\mathbf{( m )}\end{array}$ \\
\hline 1 & 19.4 .2002 & $09: 41: 36.5$ & 6792766.0 & 1525527.0 & -152.8 \\
\hline 2 & 23.4 .2002 & $17: 55: 47.4$ & 6792785.5 & 1525545.9 & -143.4 \\
\hline 3 & 8.5 .2002 & $00: 10: 04.2$ & 6792017.5 & 1525408.3 & -81.4 \\
\hline 4 & 24.5 .2002 & $19: 59: 35.7$ & 6791939.0 & 1525934.5 & -6030.0 \\
\hline 5 & 24.8 .2004 & $14: 45: 40.2$ & 6791924.0 & 1526224.5 & -364.8 \\
\hline
\end{tabular}

\begin{tabular}{|c|c|c|c|c|c|c|c|}
\hline $\begin{array}{l}\text { Loc. } \\
\text { Err. } \\
\text { (m) }\end{array}$ & $\begin{array}{l}\text { Mag } \\
\text { Loc }\end{array}$ & $\begin{array}{c}\text { Seismic } \\
\text { Mom. } \\
(\log 10)\end{array}$ & $\begin{array}{c}\text { Radiated } \\
\text { Energy } \\
(\log 10) \\
(J)\end{array}$ & $\begin{array}{l}\text { Size } \\
\text { (m) }\end{array}$ & ESEP & $\begin{array}{c}\text { No. } \\
\text { of } \\
\text { Acc. }\end{array}$ & No \\
\hline 0.0 & -2.9 & $6.5 \mathrm{E}+00$ & $-3.1 \mathrm{E}+00$ & 10.2 & $2.4 \mathrm{E}-01$ & 1 & 1 \\
\hline 0.0 & -3.1 & $6.1 \mathrm{E}+00$ & $-3.0 \mathrm{E}+00$ & 9.1 & $3.3 \mathrm{E}+01$ & 1 & 2 \\
\hline 0.0 & -3.2 & $6.1 \mathrm{E}+00$ & $-3.4 \mathrm{E}+00$ & 9.1 & $3.8 \mathrm{E}+00$ & 1 & 3 \\
\hline 0.9 & -0.4 & $9.0 \mathrm{E}+00$ & $2.5 \mathrm{E}+00$ & 4.1 & 0 & 5 & 4 \\
\hline 3.4 & -0.4 & $9.2 \mathrm{E}+00$ & $2.3 \mathrm{E}+00$ & 16.7 & $4.7 \mathrm{E}+00$ & 4 & 5 \\
\hline
\end{tabular}

\subsection{Foreign materials}

The use of foreign materials is restricted and regulated in the ONKALO and a list of appropriate materials that can be used in the ONKALO is established and continuously updated. Altogether 46 different materials have so far been authorised.

During the first $990 \mathrm{~m}$ of tunnel length a total of about 321 tons cement has been used. This compares well with the estimations made before the construction of the ONKALO begun.

\section{Conclusions}

Many of the possible changes caused by the construction of ONKALO are driven by the drawdown of the groundwater table, which is a consequence of the water inflow into the tunnel. Because of heavy use of cement in the upper parts of ONKALO, the water inflow is only about $16 \mathrm{l} / \mathrm{min}$ and because of that no drawdown has occurred.

Another reason why there have not been any significant changes is a fairly short time since the construction started. 


\section{References}

[1] Ahokas, H., Klockars, J. \& Lahdenperä, A-M. Results of Monitoring at Olkiluoto in 2003-2004. Hydrology. Working report 2005-28. Posiva Oy, Eurajoki, 2005.

[2] Haapanen, R. Results of Monitoring at Olkiluoto in 2004. Environment. Working report 2005-31. Posiva oy, Eurajoki, 2005.

[3] Hirvonen, H. \& Mäntynen, M. (ed.). Results of Monitoring at Olkiluoto in 2004. Geochemistry. Working report 2005-29. Posiva Oy, Eurajoki, 2005.

[4] Juhola, P. Results of Monitoring at Olkiluoto in 2004. Foreign materials. Juhola, P. Working report 2005-27. Posiva Oy, Eurajoki, 2005.

[5] Posiva Oy. Baseline conditions at Olkiluoto. Posiva 2003-02. Posiva Oy, Eurajoki, 2003.

[6] Posiva Oy. ONKALO Underground Rock Characterization Facility - main drawings stage. Working report 2003-26. Posiva Oy, Eurajoki, 2003.

[7] Posiva Oy. Programme of Monitoring at Olkiluoto During Construction and Operation of the ONKALO. Posiva 2003-05. Posiva Oy, Eurajoki, 2003.

[8] Posiva Oy. TKS-2006. Nuclear waste management of the Olkiluoto and Loviisa power plants: Programme for Research, Development and Technical Design for 2007-2009 (in prep).

[9] Riikonen, S. (ed.) Results of Monitoring at Olkiluoto in 2004. Rock mechanics. Working report 2005-30. Posiva Oy, Eurajoki, 2005.

[10] Saari, J. Seismic Network at the Olkiluoto Site. Working Report 2003-37. Posiva Oy, Eurajoki, 2003. 